Al-Manhaj: Jurnal Hukum dan Pranata Sosial Islam

Vol. : : 2 (2), 2020, 216-237

P-ISSN : 2686-1607

E-ISSN : 2686-4819

\title{
RELEVANSI PENERAPAN PRODUK MULTIJASA PADA ISLAMIC MICROFINANCE INSTITUTIONS DENGAN KESEJAHTERAAN MASYARAKAT
}

\author{
Eny Latifah, Cindy Andini Fariskasari \\ Institut Agama Islam Tarbiatut Tholabah Lamongan \\ email: eni.lathifah@gmail.com, cindyandini237@gmail.com
}

\begin{abstract}
The purpose of this was to determine the application and relevance of multi-service products in the form of overseas money transfer services in the Islamic microfinance institutions namel the TKI Artha Mulya Sharia., as well as the economy Welfare of the community, especially members of the TKI Artha Mulya Sharia Lamongan. The result of this reseach are the application of overseas money transfer service to the TKI Artha Mulya Sharia is based on the ijarah and wakalah contracs. The existence of overseas money transfer service greatly affects the welfare of the economy. This can be seen where the majority of the community also work as migrant Workers abroad. So that, overseas money transfer service is most superior service in this TKI Artha Mulya Sharia Cooperative, because this service can help the wider community, aspecially TKI in sending money to the families, because the community is still weak in using the internet.
\end{abstract}

Keywords: Multi-service, Welfare, Islamic microfinance institutions

Abstrak: Tujuan penelitian ini adalah ingin mengetahui penerapan dan relevansi produk multijasa pengiriman uang luar negeri di Islamic Microfinance Institutions yang bernama koperasi syariah TKI Artha Mulya serta dengan kesejahteraan perekonomian msyarakat khususnya anggota Koperasi Syariah TKI Artha Mulya Lamongan. Hasil penelitian adalah penerapan 
dari jasa keuangan luar negeri pada Koperasi Syariah TKI Artha Mulya ini didasarkan pada akad ijarah dan akad wakalah. Adanya jasa pengiriman uang luar negeri sangat berpengaruh terhadap kesejahteraan perekonomian .Hal ini dapat dilihat dimana mayoritas masyarakatnya juga berprofesi sebagai TKI di luar negeri. Sehingga jasa pengiriman uang luar negeri ini menjadi jasa yang paling diunggulkan pada Koperasi Syariah TKI Artha Mulya ini, karena jasa ini bisa membantu masyarakat luas khususnya para TKI dalam mengirimkan uang kepada keluarganya karena masyarakat masih lemah dalam penggunaan internet.

Kata Kunci: Multijasa, Kesejahteraan, Islamic microfinance intitutions.

\section{PENDAHULUAN}

Islamic Microfinance Institutions di Indonesia menjadi lembaga keuangan alternatif yang diminati masyarakat khususnya tingkat UKM karena memiliki prosedur yang tidak menyulitkan masyarakat bila dibandingkan dengan Perbankan. Bentukbentuknya juga beraneka ragam dengan nama-nama yang sesuai operasional instutusi keuangan, ada yang bentunknya BMT, Koperasi Syariah, Koperasi Simpan Pinjam Pembiayaan Syariah. Unit Usaha Pembiayaan Syariah dan lain-lain.

Lembaga keuangan mikro syariah memiliki segmen pasar yang sudah jelas, yaitu masyarakat-masyarakat level menengah kebawah. Sehibgga kegiatan lembaga keuangan mikro syariah banyak berpusat disentra-sentra bisnis pada masyarakat level mikro dan menengah. Lembaga keuangan mikro syariah memiliki karakteristik yang dekat dengan masyarakat, bahkan tidak jarang pula lembaga keuangan mikro syariah berusaha untuk 
bersosialisasi dan datang langsung ke masyarakat untuk menawarkan jasa-jasa yang ditawarkan. Hal tersebut yang membuat lembaga keuangan mikro syariah menjadi populer dan dekat dengan masyarakat. ${ }^{1}$

Koperasi syariah merupakan salah satu lembaga keuangan mikro yang kegiatannya adalah menghimpun dana dari anggota dan menyalurkannya kepada anggota untuk mensejahterakan taraf hidup para anggota koperasi maupun masyarakat sekitar dengan menggunakan prinsip yang sesuai dengan prinsip syariah. ${ }^{2}$

Koperasi syariah sebagai salah satu lembaga keuangan syariah harus menunjukkan konsistensinya sebagai suatu industri yang mampu bertahan dan menghadapi perkembanganperkembangan yang ada. Sebagai salah satu usaha lembaga keuangan syariah dalam menghadapi perkembangan yang ada ini adalah salah satunya dengan mengembangkan dan terus menginovasi produk-produk dan jasa keuangan yang ditawarkan. Jika suatu lembaga keuangan syariah mampu menciptakan produk dan jasa yang bisa menyesuaikan dengan perkembangan dan kondisi masyarakat yang ada, lembaga keuangan syariah pastinya akan mampu memperkuat posisinya dalam industri keuangan di Indonesia. ${ }^{3}$

1 Rifki Muhammad, Akuntansi Keuangan Syariah (Yogyakarta: P3EI Press, 2010), 51. 2013), 5.

2 G. Kartasapoetra, Praktek Pengelolaan Koperasi (Jakarta: Rineka Cipta,

3 Fitra Rizal and Azidni Rofiqo, "Determinants of Sharia Banking Profitability: Empirical Studies in Indonesia 2011-2020," El Barka: Journal of Islamic Economic and Business 3, no. 1 (2020): 137-61, https://doi.org/10.21154/elbarka.v3i1.2051. 
Eny Latifah \& Cindy Andini Fariskasari, Relevansi Penerapan Produk Multijasa ... 219

Koperasi Syariah TKI Artha Mulya Sugihan merupakan suatu lembaga keuangan mikro yang menjalankan usahanya sesuai dengan prinsip syariah yang memiliki tujuan untuk kesejahteraan bersama. Koperasi Syariah TKI Artha Mulya muncul karena gagasan para purna TKI yang ada di Desa Sugihan untuk menyatukan visi dan misi untuk mengembangkan ekonomi kerakyatan yang sesuai dengan prinsip syariah. Selain tujuan tersebut, gagasan purna TKI juga tidak terlepas terhadap kesejahteraan perekonomian para TKI. Hal itu dikarenakan di Desa Sugihan sendiri sangat banyak yang menjadi TKI, sehingga pendirian Koperasi Syariah TKI Artha Mulya diharapkan akan membantu mensejahterakan perekonomian tidak hanya masyarakat sekitar, tetapi juga para TKI yang sedang bekerja di luar negeri. Hal ini perlu dilihat dengan adanya salah satu jasa yang ditawarkan oleh Koperasi Syariah TKI Artha Mulya yang dianggap paling bisa membantu para TKI di luar negeri, yaitu jasa pengiriman uang luar negeri. ${ }^{4}$

Jasa pengiriman uang luar negeri adalah suatu jasa yang ditawarkan oleh Koperasi Syariah TKI Artha Mulya yang digunakan untuk membantu para TKI dalam mengirimkan uang kepada keluarganya dengan didasarkan pada akad wakalah dan ijarah, dimana terdapat proses perwakilan dan ujrah atau upah sebagai imbalan atas jasa yang telah diberikan dengan ketentuan yang telah disepakati di awal.

4 Sambutan oleh Bapak Khoirun Nasirin selaku Ketua Koperasi Syariah TKI Artha Mulya pada acara RAT (Rapat Anggota Tahunan) pada 05 Februari 2020. 
Untuk mengetahui bagaimana implementasi dan seberapa besar pengaruh jasa pengiriman uang luar negeri yang ditawarkan oleh Koperasi Syariah TKI Artha Mulya terhadap kesejahteraan TKI di Lamongan, maka penulis tertarik dengan bagaimana implementasi jasa pengiriman uang luar negeri yang ada di Koperasi Syariah TKI Artha Mulya Lamongan. Sehingga penulis melakukan pengkajian lebih dalam dengan mengangkat judul "Relevansi Penerapan Produk Multijasa Pada Islamic Microfinance Institutions Dengan Kesejahteraan Ekonomi” Dengan studi kasus pada koperasi syariah TKI Artha Mulya Lamongan.

\section{PENGERTIAN MULTIJASA}

Kata multijasa berasal dari dua kata, yaitu multi yang berarti banyak, bermacam-macam dan kata jasa yang berarti perbuatan yang berguna atau bernilai bagi orang lain atau bermanfaat bagi orang lain. menurut fatwa Dewan Syariah Nasional No. 44/DSN-MUI/VII/2004 tentang pembiayaan multijasa, bahwa salah satu bentuk pelayanan jasa keuangan yang menjadi kebutuhan masyarakat adalah pembiayaan multijasa. ${ }^{5}$

Menurut Wangsawidjaja, multijasa merupakan suatu jasa yang ditawarkan oleh lembaga keuangan syariah kepada nasabah untuk pemenuhan jasa-jasa tertentu, seperti pendidikan, kesehatan, dan jasa-jasa lainnya. ${ }^{6}$

5 Abdul Rohman Ghazaly, Fiqih Muamalah (Jakarta: Kencana Premedia Group, 2010), 284.

6 Wangsawidjaja Z., Pembiayaan Bank Syariah (Jakarta: Gramedia Pustaka Utama, 2013), 228. 
Eny Latifah \& Cindy Andini Fariskasari, Relevansi Penerapan Produk Multijasa ... 221

Multijasa merupakan suatu jasa yang diberikan oleh lembaga keuangan syariah kepada nasabah dalam memperoleh manfaat atas suatu jasa. Dalam fatwa DSN sendiri, multijasa hukumnya boleh dengan menggunakan akad ijarah. Keuntungan yang diperoleh dari multijasa tersebut berbentuk imbalan jasa atau fee yang biasanya disebut ujrah. Besarnya ujrah harus disepakati di awal dan dinyatakan dalam bentuk nominal, bukan dalam bentuk presentase. Multijasa biasanya dikeluarkan oleh suatu lembaga keuangan syariah agar lembaga tersebut bisa survive dan bersaing dengan lembaga keuangan lainnya. ${ }^{7}$

Pembolehan akan adanya orang yang diberi upah atas suatu jasa terhadap orang lain telah dibenarkan sejak zaman Rasulullah SAW. Hal ini dapat dilihat dalam dasar-dasar syariah berikut ini: ${ }^{8}$ (1) Dasar hukum dalam Al-Qur'an QS. Al Baqarah ayat 233, (2) Dasar hukum dalam As-Sunah; yang artinya, "dari Ibnu Umar r.a, bahwa Rasulullah SAW bersabda, berikanlah upah kepada pekerja sebelum keringatnya mengering" (HR. Ibnu Majah). ${ }^{9}$ (3) Dasar hukum dalam Ijma', semua ulama' pada zaman sahabat telah sepakat akan diperbolehkannya penerapan multijasa dengan menggunakan akad ijarah. Hal ini didasarkan pada kebutuhan masyarakat atas jasa-jasa tertentu. Ketika akad jual beli diperbolehkan, terdapat suatu kewajiban untuk membolehkan akad ijarah atas manfaat suatu jasa. Karena pada hakikatnya

7 Ikatan Bankir Indonesia, Menguasai Fungsi Kepatuhan Bank (Jakarta: PT Gramedia Pustaka Utama, 2015), 150.

${ }^{8}$ Abdul Rohman Ghazaly, Fiqih Muamalah, 277.

${ }^{9}$ Ghazaly, 278. 
multijasa merupakan akad jual beli, tetapi dengan objek manfaat atau jasa. ${ }^{10}$

\section{TENAGA KERJA INDONESIA (TKI)}

Tenaga kerja merupakan individu yang sedang mencari atau sudah melakukan pekerjaan yang menghasilkan barang atau jasa yang sudah memenuhi persyaratan ataupun batasan usia yang telah ditetapkan oleh Undang-undang yang bertujuan untuk memperoleh hasil atau upah untuk memenuhi kehidupannya sehari-hari. ${ }^{11}$

Tenaga Kerja Indonesia yang selanjutnya disebut dengan TKI adalah setiap warga negara Indonesia yang memenuhi syarat untuk bekerja di luar negeri dalam hubungan kerja untuk jangka waktu tertentu dengan menerima upah. Arti lain dari TKI adalah warga negara Indonesia baik laki-laki maupun perempuan yang melakukan kegiatan di bidang perekonomian, sosial, keilmuwan, kesenian dan olahraga profesional yang mengikuti pelatihan kerja di luar negeri baik darat, laut, maupun udara dalam jangka waktu tertentu berdasarkan perjanjian antara pekerja dan pengusaha secara lisan atau tertulis untuk waktu tertentu yang memuat syarat-syarat kerja, hak, dan kewajiban para pihak. ${ }^{12}$

Dari definisi di atas, dapat ditarik kesimpulan bahwa yang dimaksud dengan Tenaga Kerja Indonesia (TKI) adalah individu

10 Dimyauddin Djuwaini, Pengantar Fiqh Muamalah (Yogyakarta: Pustaka Pelajar, 2010), 156.

11 Sendjun H. Manululang, Pokok-pokok Hukum Ketenagakerjaan di Indonesia (Jakarta: PT Rineka Citra, 1998), 3.

12 Manululang, 5. 
Eny Latifah \& Cindy Andini Fariskasari, Relevansi Penerapan Produk Multijasa ... 223 yang mampu bekerja dalam rangka menghasilkan jasa guna untuk memenuhi kebutuhan hidupnya.

Dalam buku pedoman penempatan tenaga kerja ke luar negeri disebutkan tujuan dari TKI ke luar negeri yang meliputi: (1)Perluasan lapangan kerja, (2) Peningkatan kualitas tenaga kerja, (3)Peningkatan perlindungan tenaga kerja, (4) Peningkatan kesejahteraan tenaga kerja, (5)Peningkatan penerimaan devisa negara. ${ }^{13}$

Menjadi Tenaga Kerja Indonesia (TKI) adalah menjadi tenaga kerja di negara lain dengan berbagai tujuan yang telah dijelaskan di atas. Tujuan utama menjadi TKI adalah untuk meningkatkan taraf hidup dan keluarganya baik dari segi ekonomi maupun sosial. Sehingga umumnya mereka mencari pekerjaan yang dapat memberikan pendapatan dan status sosial yang lebih baik di negara tujuan. ${ }^{14}$

\section{KESEJAHTERAAN EKONOMI}

Definisi kesejahteraan dalam konsep dunia modern adalah sebuah kondisi dimana seorang dapat memenuhi kebutuhan pokok, baik itu kebutuhan akan makanan, pakaian, tempat tinggal, air minum yang bersih, serta kesempatan untuk melanjutkan pendidikan dan memiliki pekerjaan yang memadai yang dapat menunjang kualitas hidupnya, sehingga memiliki status sosial yang

13 Depnaker, Pedoman Penempatan Kerja Ke Luar Negeri, Dirjen Pembinaan Penempatan Tenaga Kerja (Jakarta: 1994), 4.

14 Sendjun H. Manululang, Pokok-pokok Hukum Ketenagakerjaan di Indonesia, 10. 
mengantarkan pada status sosial sama terhadap sesama warga lainnya. ${ }^{15}$

Kesejahteraan merupakan salah satu aspek yang cukup penting untuk menjaga dan membina terjadinya suatu stabilitas sosial dan ekonomi. Dimana kondisi tersebut juga diperlukan untuk meminimalkan terjadinya kecemburuan sosial dalam masyarakat. maka setiap individu membutuhkan kondisi yang sejahtera dalam hal materil dan dalam hal non materil, sehingga dapat terciptanya suasana yang harmonis dalam bermasyarakat. ${ }^{16}$

Ekonomi memiliki tugas untuk memberi prinsip yang rasional bagi bisnis sebagai kegiatan ekonomi, sehingga kegiatan ekonomi tersebut tidak hanya mengarah diri pada kebutuhan hidup manusia perorang dan jangka pendek, tetapi juga memberi surplus bagi kesejahteraan banyak orang dalam negara. Kompetisi dalam pasar juga bisa menimbulkan dampak negatif untuk terwujudnya kesejahteraan ekonomi. Kesejahteraan ekonomi sangat berperan penting dalam membangun suatu kegiatan ekonomi yang dapat memberikan atau menciptakan suatu kondisi yang sejahtera dalam skala bermasyarakat ataupun lingkungan keluarga. ${ }^{17}$

Kesejahteraan ekonomi dalam konteks syariah bertujuan untuk mencapai kesejahteraan manusia secara menyeluruh, yaitu kesejahteraan material, kesejahteraan spiritual maupun

15 Ikhwan Abidin Basri, Islam dan Pembangunan Ekonomi (Jakarta: Gema Insani Press, 2005), 24.

16 Basri, 26. 56.

17 Dominick Salvatone, Teori Mikroekonomi (Jakarta: Erlangga, 2009), 
Eny Latifah \& Cindy Andini Fariskasari, Relevansi Penerapan Produk Multijasa ... 225 kesejahteraan moral. Konsep ekonomi kesejahteraan syariah bukan saja berdasarkan manifestasi nilai ekonomi, tetapi juga nilai moral dan spiritual, nilai sosial dan nilai politik Islami. ${ }^{18}$

Kesejahteraan ekonomi dapat dilihat berdasarkan tingkatannya, tingkatan dari kesejahteraan ekonomi sendiri meliputi:19

1. Kesejahteraan perorangan

Kesejahteraan perorangan meliputi kesejahteraan kejiwaan perorangan yang diakibatkan oleh pendapatan, kemakmuran dan faktor ekonomis lainnya. Kesejahteraan perorangan merupakan sinonim dengan tingkat terpenuhinya kebutuhan dari diri seorang individual. Sepanjang terpenuhinya kebutuhan ini tergantung dari faktor-faktor ekonomis.

2. Kesejahteraan masyarakat

Kesejahteraan masyarakat ini menyangkut kesejahteraan semua perorangan secara keseluruhan anggota masyarakat. dalam hal ini, kesejahteraan yang dimaksudkan adalah kejahteraan masyarakat, kesejahteraan dari beberapa individu atau kesejahteraan bersama.

Adapun tahapan yang harus diperhatikan dalam meningkatkan kesejahteraan masyarakat diantaranya adalah:

1. Adanya persediaan sumber-sumber pemecahan masalah yang dapat digunakan. Dalam hal ini memang harus diperhatikan guna menyelesaikan permasalahan yang ada, khususnya dalam hal meningkatkan kesejahteraan. Karena tanpa adanya sumber pemecahan masalah, maka masalah tersebut akan tetap ada.

18 Ikhwan Abidin Basri, Islam dan Pembangunan Ekonomi, 26.

19 Basri, 85. 
2. Pelaksanaan usaha dalam menggunakan sumber-sumber pemecahan masalah harus efisien dan tepat guna. Pada tahap ini, seseorang harus dapat menyesuaikan antara masalah dengan sumber pemecahan masalah yang tepat dan dapat diselesaikan dengan cepat.

3. Pelaksanaan usaha meningkatkan kesejahteraan harus bersifat demokratis. Dalam hal ini, meningkatkan kesejahteraan suatu masyarakat lebih baik masyarakat tersebut dilibatkan didalamnya.

4. Mencegah dampak butuk dari suatu usaha. Hal ini juga harus diperhatikan dalam meningkatkan kesejahteraan ekonomi masyarakat luas. Dalam melakukan suatu usaha haruslah dapat membantu meningkatkan kesejahteraan masyarakat luas juga, sehingga akan menimbulkan dampak yang positif. ${ }^{20}$

\section{ISLAMIC MICROFINANCE INSTITUTION}

Lembaga Keuangan Mikro Syariah atau Islamic Microfinance Institutions adalah Lembaga keuangan yang beroperasional dengan memperhatikan prinsip dan nilai-nilai ekonomi Islam. Salah satu nilai-nilai ekonomi Islam yang harus ada dalam lembaga keuangan syariah ini adalah amanah. Karena sebuah lembaga yang menerima amanah dari anggotanya atau nasabahnya untuk mengelola dan menyimpan dana (uang) yang dimilikinya agar bisa dijaga dan di manfaatkan dengan sebaik mungkin untuk kepentingan ummat.

20 Basri, 86. 
Eny Latifah \& Cindy Andini Fariskasari, Relevansi Penerapan Produk Multijasa ... 227

Lembaga keuangan syariah yang ruang lingkupnya mikro seperti Baitul Maal Wattamwil dan Koperasi Syariah merupakan lembaga keuangan yang ditumbuhkan dari peran masyarakat secara luas, tidak ada batasan ekonomi, sosial bahkan agama, semua komponen masyarakat dapat berperan aktif dalam membangun sebuah sistem keuangan yang lebih adil dan yang lebih pentinag mampu menjalankan lapisan pengusaha yang terkecil sekalipun. Dalam kegiatan keuangan syariah, seluruh transaksi yang terjadi harus dilaksanakan berdasarkan prinsipprinsip syariah. Prinsip syariah adalah prinsip hukum Islam dalam kegiatan perbankan dan keuangan berdasarkan fatwa yang dikeluarkan oleh lembaga yang memiliki kewenangan dalam penetapan fatwa di bidang syariah. Prinsip syariah yang dianut oleh lembaga keuangan syariah dilandasi oleh nilai-nilai keadilan, kemanfaatan, keseimbangan, dan universal. ${ }^{21}$

Lembaga Keuangan Mikro Islam (Islamic Microfinance Institution) adalah Koperasi Syariah TKI Artha Mulya di tahun 2019, melakukan Perubahan Anggaran Dasar (PAD) dengan sektor usaha utama dibidang jasa, dan usaha tambahan simpan pinjam syariah, dengan rincian sebagai berikut: (1) Simpanan yang terdiri dari: Simpanan umum Syari'ah, Simpanan peduli Siswa, Simpanan Haji dan Umroh, Simpanan hari raya, Simpanan berjangka syariah, Simpanan ziarah/wisata religi dan Simpanan barokah keluarga (SIBERKAH). (2) Produk Pembiayaan Modal Usaha ang meliputi: Mudharabah (Bagi hasil), Musyarakah (Penyertaan), Murabahah

21 Fitra Rizal. "Pengaruh Capital Adequacy Ratio, Non Performing Finance dan Operational Efficiency Ratio Terhadap Profitabilitas Bank Pembiayaan Rakyat Syariah." Muslim Heritage 1.1 (2016): 179-196. 
(Jual beli), Qordul hasan (Kebajikan) dan Ijarah (Sewa). (3) Produk Jasa Layanan yang meliputi: Pertokohan, Toko pertanian, PPOB (Payment Point Online Banking), ATM mini, Pengiriman uang luar Negeri, Penukaran mata uang asing, Foto copy, Counter pulsa, Sewa tarup, Perpanjang STNK dan Grosir.

\section{SEJARAH KOPERASI SYARIAH TKI ARTHA MULYA}

Koperasi Syariah TKI Artha Mulya pertama kali digagas pada tahun 2011 atas prakarsa para TKI dan purna TKI yang ada di Desa Sugihan yang memiliki visi dan misi yang sama dalam mengembangkan ekonomi kerakyatan. Dimana wilayah kerjanya adalah di Malaysia dan masih serabutan, masih belum ada kantor dan badan hukum yang sah. Pada tahun 2012 tepatnya pada tanggal 17 Agustus, terbentuklah "Koperasi Simpan Pinjam Syariah" dengan Badan Hukum No. 518/BH/XVI.01/673/413.111/2013 dan telah memiliki kantor sendiri yang beralamatkan di Jl. Merdeka No. 05 Sugihan tepatnya pada tahun 2013 .

Berdasarkan rapat anggota pada tanggal 02 Januari 2015 berubah nama menjadi "Koperasi Syariah Artha Mulya". Antusias dari masyarakat sangat luar biasa, hal itu dapat dilihat dari banyaknya masyarakat yang melaksanakan transaksi, baik itu pinjaman usaha maupun dalam bentuk simpanan. Karena semakin antusiasnya masyarakat sekitar dalam melakukan transaksi, maka pengurus Koperasi melakukan pengembangan usaha yang berupa beberapa unit usaha. Selain menambah unit usahanya, koperasi 
Eny Latifah \& Cindy Andini Fariskasari, Relevansi Penerapan Produk Multijasa ... 229 juga melakukan trobosan dengan melakukan pembukaan cabang koperasi di beberapa kecamatan yang ada di kabupaten Lamongan. Hal ini bertujuan untuk meningkatkan usaha koperasi.

Pada bulan September 2019 lalu, Koperasi Syariah Artha Mulya berubah nama menjadi "Koperasi Syariah TKI Artha Mulya” dengan Badan Hukum No. 518/BH/XVI.01/673/413.111/2013 PAD No. 0012/PAD/M.KUKM.2/IX/2019. Hal tersebut ditujukan untuk mempresentasikan dan menggambarkan bahwa Koperasi Syariah TKI Artha Mulya merupakan gagasan dari TKI dan purna TKI.

\section{PENERAPAN PRODUK MULTIJASA PADA ISLAMIC MICROFINANCE INSTITUTIONS}

Koperasi Syariah TKI Artha Mulya merupakan salah satu lembaga keuangan mikro syariah yang ada di Desa Sugihan. Dalam perannya untuk kesejahteraan masyarakat, Koperasi Syariah TKI Artha Mulya mengembangkan beberapa produk jasa yang digunakan untuk pelayanan bagi setiap anggotanya. Salah satu produk jasa yang dikembangkan oleh Koperasi Syariah TKI Artha Mulya adalah "Jasa Pengiriman Uang Luar Negeri”. Jasa pengiriman uang luar negeri atau money express adalah sebuah layanan yang memfasilitasi masyarakat yang berada di luar negeri yang ingin mengirimkan sejumlah uangnya kepada keluarganya atau orang yang bersangkutan lainnya yang berada di dalam negeri atau di suatu desa melalui perantara suatu lembaga keuangan.

Implementasi dari jasa keuangan luar negeri pada Koperasi Syariah TKI Artha Mulya ini didasarkan pada akad ijarah dan akad 
wakalah. Dimana pihak masyarakat atau TKI yang ingin mengirimkan uangnya kepada keluarganya tersebut mewakilkan kepada koperasi untuk memberikan uang kirimannya kepada keluarganya yang ada di rumah. Kemudian pihak koperasi langsung memproses kiriman tersebut dengan mengantarkan kiriaman tersebut langsung ke rumah orang yang dituju. Berdasarkan jasa yang telah dilakukan oleh koperasi tersebut, maka pihak koperasi berhak mendapatkan upah atau ujrah sebagai imbalan atas jasa yang telah dilakukan. Hal tersebut didasarkan atas akad ijarah. ${ }^{22}$

Akad wakalah dalam pengertiannya yaitu pelimpahan kekuasaan oleh seseorang yang disebut sebagai pihak pertama kepada orang lain sebagai sebagai pihak kedua dalam melakukan sesuatu berdasarkan kuasa atau wewenang yang diberikan oleh pihak pertama, akan tetapi apabila kuasa itu telah dilaksanakan sesuai dengan yang disyaratkan atau yang telah ditentukan, maka semua risiko dan tanggung jawab atas perintah tersebut sepenuhnya menjadi pihak pertama atau pemberi kuasa. Dalam arti lain, wakalah adalah tindakan seseorang yang mewakilkan dirinya kepada orang lain untuk melakukan kegiatan lain, yaitu untuk melakukan kegiatan yang merupakan haknya. ${ }^{23}$

Wakalah dalam praktek pengiriman atas suatu barang terjadi seseorang menunjuk orang lain atau untuk mewakili

22 Wawancara ekslusif dengan Erni Wulandari selaku asisten Project Officer Koperasi Syariah TKI Artha Mulya Sugihan pada 08 Februari 2020. 2002), 20.

23 Helmi Karim, Fiqh Muamalah (Jakarta: PT Raja Grafindo Persada, 
Eny Latifah \& Cindy Andini Fariskasari, Relevansi Penerapan Produk Multijasa ... 231 dirinya mengirimkan sesuatu. Orang yang diminta diwakilkan harus menyerahkan barang yang akan dia kirimkan untuk orang lain kepada yang mewakili dalam suatu kontrak. ${ }^{24}$

Berdasarkan beberapa definisi diatas, maka dapat disimpulkan bahwa yang dimaksud dengan wakalah adalah penyerahan dari seseorang kepada orang lain untuk mengerjakan sesuatu.

Akad wakalah dalam implementasinya pada produk jasa keuangan luar negeri yang ada pada Koperasi Syariah TKI Artha Mulya Sugihan adalah dimana seseorang yang berada di luar negeri yang ingin mengirimkan uangnya kepada keluarganya mewakilkan dirinya kepada pihak koperasi untuk mengirimkan uang kirimannya tersebut kepada pihak keluarganya langsung kerumahnya. ${ }^{25}$

Sedangkan akad ijarah dalam teorinya berarti melakukan suatu akad dengan mengambil manfaat atas sesuatu yang diterima dari orang lain dengan membayar sesuai dengan perjanjian yang telah ditentukan dengan syarat-syarat tertentu pula. Dalam arti luas, ijarah bermakna suatu akad yang berisi penukaran manfaat sesuatu dengan jalan memberikan imbalan dalam jumlah tertentu. Hal ini sama artinya dengan menjual manfaat suatu benda, bukan menjual 'ain dari suatu benda itu sendiri. ${ }^{26}$ 2010), 232.

${ }^{24}$ Hendi Suhendi, Fiqh Muamalah (Jakarta: PT Raja Grafindo Persada,

25 Wawancara ekslusif dengan Erni Wulandari selaku asisten Project Officer Koperasi Syariah TKI Artha Mulya Sugihan pada 08 Februari 2020.

26 Nasrun Haroen, Fiqih Muamalah (Jakarta: Gaya Media Pratama, 2000), 228. 
Menurut Fatwa DSN MUI No. 09/DSN-MUI/IV/2000 tentang pembiayaan ijarah. Ijarah adalah akad pemindahan hak guna (manfaat) atas suatu barang atau jasa dalam waktu tertentu melalui pembayaran sewa atau upah tanpa diikuti dengan pemindahan kepemilikan barang itu sendiri. Dengan demikian akad ijarah tidak ada perubahan kepemilikan, tetapi hanya perpindahan hak guna saja dari yang menyewakan pada penyewa. ${ }^{27}$

Dari beberapa pengertian di atas, dapat disimpulkan bahwa ijarah adalah suatu jenis perikatan atau perjanjian yang bertujuan untuk mengambil manfaat suatu benda atau jasa yang diterima dari orang yang memberikan barang atau jasa yang diterima dari orang lain dengan jalan membayar upah sesuai dengan perjanjian dan kerelaan kedua belah pihak dengan rukun dan syarat yang telah dilakukan.

Akad ijarah dalam implementasinya pada produk jasa keuangan luar negeri yang ada pada Koperasi Syariah TKI Artha Mulya adalah dimana antara kedua belah pihak yaitu orang yang melakukan pengiriman dan pihak koperasi melakukan perjanjian atas jasa pengiriman uang luar negeri agar disampaikan kepada orang yang menerima kiriman dengan adanya ujrah yang harus

27 Fatwa DSN MUI No. 09/DSN-MUI/IV/2000 Tentang Pembiayaan Ijarah (Himpunan Fatwa DSN untuk Lembaga Keuangan Syariah, DSN-MUI, BI, 2001), 55. 
Eny Latifah \& Cindy Andini Fariskasari, Relevansi Penerapan Produk Multijasa ... 233 ditanggung oleh pihak pengirim kepada pihak koperasi sesuai dengan jumlah yang telah disepakati bersama. ${ }^{28}$

Berikut skema implementasi jasa pengiriman uang luar negeri pada Koperasi Syariah Artha Mulya:

1. Penyerahan uang kiriman dengan

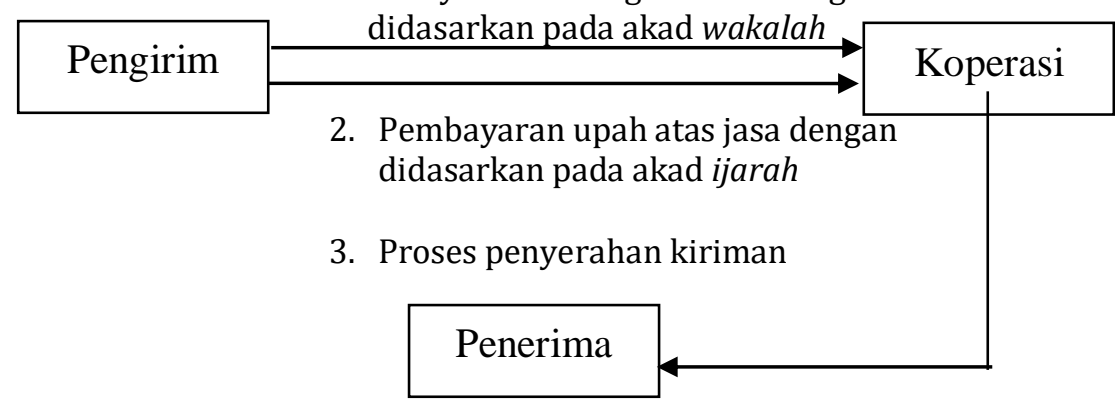

\section{Keterangan:}

1. Penyerahan uang kiriman dari pihak pengirim kepada koperasi dengan didasarkan pada akad wakalah. Dimana pihak pengirim mewakilkan uang kirimannya kepada pihak koperasi untuk disampaikan kepada pihak penerima.

2. Pihak pengirim melakukan pembayaran upah atau ujrah yang telah disepakati bersama atas jasa yang telah diberikan oleh pihak koperasi yang diberikan amanat untuk menyampaikan kiriman kepada pihak penerima. Hal tersebut didasarkan pada akas ijarah.

3. Pihak koperasi luar negeri melakukan komunikasi dengan pihak koperasi dalam negeri atas jasa keuangan berupa kiriman dari pihak pengirim agar diproses penyerahan kiriman kepada pihak penerima. $^{29}$

28 Wawancara ekslusif dengan Erni Wulandari selaku asisten Project Officer Koperasi Syariah TKI Artha Mulya Sugihan pada 08 Februari 2020.

29 Wawancara ekslusif dengan Erni Wulandari selaku asisten Project Officer Koperasi Syariah TKI Artha Mulya Sugihan pada 08 Februari 2020. 


\section{RELEVANSI PENERAPAN PRODUK MULTIJASA DENGAN KESEJAHTERAAN MASYARAKAT DI ISLAMIC MICROFINANCE INSTITUTIONS}

Koperasi Syariah TKI Artha Mulya yang ingin mensejahterakan perekonomian masyarakat luas, maka koperasi berusaha memberikan pelayanan termasuk bentuk produkproduk yang ditawarkan sesuai dengan kebutuhan masyarakat luas. Produk-produk terbaik yang ditawarkan untuk bisa memenuhi kebutuhan masyarakat luas tersebut diantaranya produk-produk simpanan, pinjaman, dan produk-produk lain.

Adanya jasa pengiriman uang luar negeri sangat berpengaruh terhadap kesejahteraan perekonomian TKI di Desa Sugihan. Hal ini dapat dilihat dimana mayoritas masyarakatnya juga berprofesi sebagai TKI di luar negeri. Sehingga jasa pengiriman uang luar negeri ini menjadi jasa yang paling diunggulkan pada Koperasi Syariah TKI Artha Mulya ini, karena jasa ini bisa membantu masyarakat luas khususnya para TKI dalam mengirimkan uang kepada keluarganya. ${ }^{30}$

Jasa pengiriman uang luar negeri ini bisa menjadi alternatif bagi masyarakat luas yang masih gagap akan teknologi atau yang biasa disebut gaptek. Seperti halnya masyarakat yang tidak memiliki ATM, tidak paham akan cara penggunaan ATM, ataupun lokasi ATM yang cukup jauh dari wilayah mereka tinggal. Sehingga dengan adanya jasa tersebut akan membantu masyarakat luas untuk tetap bisa mengirimkan dan menerima uang kiriman

30 Wawancara ekslusif dengan Masfufah Nur Rohmah selaku Kabag Usaha Koperasi Syariah TKI Artha Mulya Sugihan pada 10 Februari 2020. 
Eny Latifah \& Cindy Andini Fariskasari, Relevansi Penerapan Produk Multijasa ... 235 walaupun tanpa adanya ATM. Terlebih lagi yang biasanya menerima kiriman tersebut mayoritas orang yang sudah lanjut usia, sehingga jasa pengiriman uang luar negeri pada Koperasi Syariah TKI Artha Mulya ini sangat membantu dalam hal mensejahterakan perekonomian masyarakat luas. Terlebih lagi mayoritas masyarakat yang ada di Desa Sugihan berprofesi sebagai TKI yang bekerja di Malaysia. Sehingga jasa tersebut dapat membantu dan mempermudah para TKI dalam hal pengiriman uang. ${ }^{31}$

Prinsip-prinsip dari kesejahteraan ekonomi sendiri meliputi: (1)Kepentingan masyarakat yang lebih luas harus didahulukan dari kepentingan individu, (2)Melepas kesulitan masyarakat luas. ${ }^{32}$ Terlepas dari prinsip kesejahteraan di atas, adanya jasa pengiriman uang luar negeri menjadi jasa yang mampu membantu kesejahteraan ekonomi masyarakat TKI yang ada di Desa Sugihan. Jasa pengiriman uang luar negeri bisa membantu dan mempermudah kepentingan dan melepas kesulitan-kesulitan yang dihadapi oleh para TKI. Kesulitan yang biasanya dihadapi salah satunya adalah dengan perkembangan teknologi yang ada, tetapi tidak semua orang paham akan teknologi yang ada, sehingga kesulitan tetap akan muncul. Hal tersebutlah yang mendorong Koperasi Syariah TKI Artha Mulya untuk mengembangkan jasa berupa jasa pengiriman uang luar negeri.

31 Wawancara ekslusif dengan Masfufah Nur Rohmah selaku Kabag Usaha Koperasi Syariah TKI Artha Mulya Sugihan pada 10 Februari 2020.

32 M. B. Hendrie Anto, Pengantar Ekonomika Mikro Islami (Yogyakarta: Ekonisia, 2003), 7. 


\section{KESIMPULAN}

Implementasi dari jasa keuangan luar negeri pada Koperasi Syariah TKI Artha Mulya ini didasarkan pada akad ijarah dan akad wakalah. Adanya jasa pengiriman uang luar negeri sangat berpengaruh terhadap kesejahteraan perekonomian TKI di Desa Sugihan. Hal ini dapat dilihat dimana mayoritas masyarakatnya juga berprofesi sebagai TKI di luar negeri. Sehingga jasa pengiriman uang luar negeri ini menjadi jasa yang paling diunggulkan pada Koperasi Syariah TKI Artha Mulya ini, karena jasa ini bisa membantu masyarakat luas khususnya para TKI dalam mengirimkan uang kepada keluarganya

\section{DAFTAR PUSTAKA}

Anto, M. B. Hendrie. Pengantar Ekonomi Mikro Islami. Yogyakarta: Ekonosia. 2003.

Basri, Ikhwan Abidin. Islam dan Pembangunan Ekonomi. Jakarta: Gema Insani Press. 2005.

Deliyani, Indah. Analisa Terhadap Aplikasi Pembiayaan Ijarah Multijasa Pada BMT Al-Munawwarah. Jakarta: Universitas Islam Negeri Syarif Hidayatullah. 2008.

Depnaker. Pedoman Penempatan Kerja Ke Luar Negeri, Dirjen Pembinaan Penempatan Tenaga Kerja. Jakarta. 1994.

Djuwaini, Dimyauddin. Pengantar Fiqh Muamalah. Yogyakarta: Pustaka Pelajar. . 2010.

Fatwa DSN MUI No. 09/DSN-MUI/IV/2000 Tentang Pembiayaan Ijarah. Himpunan Fatwa DSN untuk Lembaga Keuangan Syariah, DSN-MUI, BI, 2001.

Ghazaly, Abdul Rohman. Fiqih Muamalah. Jakarta: Kencana Premedia Group. 2010.

Haroen, Nasrun. Fiqih Muamalah. Jakarta: Gaya Media Pratama. 2000. 
Hatmasari, Puri Risma. Analisis Implementasi Produk Ijarah Multijasa Di BPR Syariah Artha Amanah Ummat Ungaran. Salatiga: Institut Agama Islam Negeri Salatiga. 2016.

Ikatan Bankir Indonesia. Menguasai Fungsi Kepatuhan Bank. Jakarta: PT Gramedia Pustaka Utama. 2015.

Karim, Helmi. Fiqih Muamalah. PT Raja Grafindo Persada. 2002.

Kartasapoetra, G. Praktek Pengelolaan Koperasi. Jakarta: Rineka Cipta. 2013.

Manulalang, Sendjun H. Pokok-Pokok Hukum Ketenagakerjaan Di Indonesia. Jakarta: PT Rineka Citra. 1998.

Rahmah, Afifah Fatur. Mekanisme Pembiayaan Multijasa Menggunakan Akad Ijarah Pada PT BPRS Al-Wasliyah Medan. Sumatera Utara: Universitas Islam Negeri Sumatera Utara. 2019.

Rifki, Muhammad. Akuntansi Keuangan Syariah. Yogyakarta: P3EI Press. 2010.

Rizal, Fitra. "Pengaruh Capital Adequacy Ratio, Non Performing Finance dan Operational Efficiency Ratio Terhadap Profitabilitas Bank Pembiayaan Rakyat Syariah." Muslim Heritage 1.1 (2016).

Rizal, Fitra, and Azidni Rofiqo. "Determinants of Sharia Banking Profitability: Empirical Studies in Indonesia 2011-2020." El Barka: Journal of Islamic Economic and Business 3, no. 1 (2020): 137-61. https://doi.org/10.21154/elbarka.v3i1.2051.

Salvatone, Dominick. Teori Mikroekonomi. Jakarta: Erlangga. 2009. Sambutan oleh Bapak Khoirun Nasirin selaku Ketua Koperasi Syariah TKI Artha Mulya pada acara RAT (Rapat Anggota Tahunan) pada Tanggal 05 Februari 2020.

Suhendi, Hendi. Fiqh Muamalah. Jakarta: PT Raja Grafindo Persada. 2010.

Z. Wangsawidjaja. Pembiayaan Bank Syariah. Jakarta: Gramedia Pustaka Utama. 2013. 